\title{
Key Definitions of STEM Education: Literature Review
}

\author{
Uswatun Hasanah ${ }^{1 \star}$
}

\begin{abstract}
${ }^{1}$ Graduate School for International Development and Cooperation, Hiroshima University, JAPAN
"Corresponding Author: uswatunhasanah216@yahoo.com
\end{abstract}

Citation: Hasanah, U. (2020). Key definitions of STEM education: Literature review. Interdisciplinary Journal of Environmental and Science Education, 16(3), e2217. https://doi.org/ 10.29333/ijese/8336

\begin{tabular}{|c|c|}
\hline RTICLE INFO & ABSTRACT \\
\hline $\begin{array}{l}\text { Received: } \\
25 \text { November } 2019\end{array}$ & $\begin{array}{l}\text { This literature review aims to identify common theme in STEM education and to find out the scope of STEM } \\
\text { education from previous studies that would provide information to researchers as well as the stakehold- } \\
\text { ers on how they should focus on the implementation of STEM education. The author creates the research }\end{array}$ \\
\hline $\begin{array}{l}\text { Accepted: } \\
21 \text { April } 2020\end{array}$ & $\begin{array}{l}\text { questions, "What are the common themes in STEM education?" and "What are scopes in STEM education } \\
\text { that can cover the common themes based on the literature reviews?". The literature search in electronic } \\
\text { databases was conducted through the Education Resources Information Center, Scopus, Web of Science } \\
\text { and Google Scholar using the varieties of Keyword such as "STEM education", "STEM Implementation", } \\
\text { "STEM definitions", "Instruction", "Curriculum", "Major", "Career". The author concludes that the defi- } \\
\text { nitions of STEM education depend on the stakeholders in the implementation. Four key definitions } \\
\text { and three scopes that cover those key definitions based on literature reviews are found and discussed. }\end{array}$ \\
\hline
\end{tabular}

Keywords: STEM education, STEM definitions, STEM disciplines, instruction, major career

\section{INTRODUCTION}

STEM education is initially called Science, Mathematics, Engineering, and Technology (SMET) and was an initiative as STEM by the National Science Foundation (NSF), which stands for science, technology, engineering, and mathematics in 1990 (Sanders, 2009). "S" for Science is very concerned with what is the natural world and preparing students to think and act like real scientists, ask questions, hypothesize, and conduct investigations using standard science practices (Burghardt \& Hacker, 2004; Kelley \& Knowles, 2016). These courses deal with physics, biology, chemistry, astronomy, etc. Meanwhile, " $T$ " technology is the modification of the natural world to meet human wants and needs. It is very concerned with what can and should be (designed, made, and developed) from natural world materials and substances to satisfy human needs and wants. Besides, "E" engineering stands as a profession in which knowledge of the mathematical and natural with judgment to improve ways to utilize the materials and forces of nature economically for the benefit of humankind. Meanwhile, "M" mathematics is defined as the science of patterns and relationship that provides the exact language for technology, science, and engineering (Dugger, 2010). The understanding of these

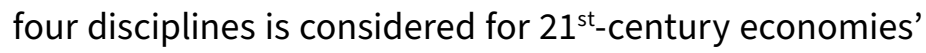
development. Hence, many countries are trying to improve the quality of education with given subjects such as science, technology, engineering, and mathematics (Yildirim, 2016).

STEM education is an integration of those four disciplines with two possibilities: as an input and output in education. National Research Council (1996) in (Bozkurt, Ucar, Durak, \& Idin, 2019) and Sander (2009) described STEM education as a teaching and learning method that integrates the content and skills of science, technology, engineering and math which is functioned as an input. Otherwise, STEM also is connected to economic competitiveness in the global market and to fill recent requests such as guaranteeing adequate and maintaining energy and productivity that is managed as an output (Boe, Henriksen, Lyons, \& Schreiner, 2011).

In general, STEM education refers to providing opportunities for students to be able to solve problems, to be innovators, inventors, self-confident, logical thinkers, and technologically literate (Morrison, 2006; Stohlmann, 
Moore, \& Roehrig, 2011). Breiner, Harkness, Johnson, and Koehler (2012) and Kelly \& Knowles (2016) revealed that STEM education has been contemplated since the 1990s and can be successful in K-16 education in preparing competent students at all levels with the skills in the rapidly expanding scientific society especially for the future success of the students. Improving STEM education may also increase the literacy of all people across the population in technological and scientific areas (NAE \& NRC, 2009; Pleasants et al., 2019).

Few stakeholders seemed to know how to operationalize STEM education several years later because it has been unclear about how the stakeholders can start with STEM implementation. There is no clarification about the standard definitions of STEM education. This literature review is conducted in order to identify common ideas in STEM education and to find out the scope of STEM education from previous studies. The findings will provide information to researchers as well as the stakeholders on how they should focus on the implementation of STEM education. The author creates the research question:

- What are the common themes in STEM education?

-What are scopes in STEM education that can cover the common themes based on the literature reviews?

\section{METHOD}

This study was a secondary source or literature review about the definition of STEM education that was categorized based on the scope of implementation; thus, researchers as well as educators could get a picture of how they identify and implement STEM education on their study field. The literature search in electronic databases was conducted through the Education Resources Information Center (ERIC), Scopus, Web of Science and Google Scholar using the varieties of keyword such as "STEM education", "STEM Implementation", "STEM definition”, "Instruction”, Curriculum”, “Major”, "Career”.

In analyzing the data process, researcher organized data extraction and made an overview with characteristics including (a) Author, (b) and Definition on STEM education on the studies. The data extraction was conducted through reading the details of each selected articles. The STEM key definitions extracted from all articles were rearranged and similar elements were grouped, leading to four different categories that were most frequently in the articles of the literature review. This was aimed to find out the scope of the STEM education and the key definitions of STEM education.

\section{RESULT AND DISCUSSION}

In total, 17 selected studies were reviewed and published from 2010-2019. In this literature review, STEM education focused on four key definitions based on the selected studies: (a) STEM as discipline, (b) STEM as instruction, (c) STEM as field, (d) STEM as a career that is pictured in Table 1.

\section{STEM as Discipline}

The first key is the STEM discipline. Based on the literature review, 16 of 17 studies defined STEM education as discipline due to the strategy of STEM implementation that should cover two or more subjects among STEM subjects. STEM discipline becomes a fundamental part of STEM education because most of the initiatives in STEM education would be related to the disciplines. Kubat and Guray (2018) believed that these four disciplines to be taught as a holistic and an undistinguished collective, rather than teaching these four disciplines independently. Otherwise, Hobbs, Clark, \& Plant (2018) revealed five various models of STEM implementation based on the discipline:

1. The first model is "Four STEM disciplines were taught separately"; for example, in science classes, there is an updated focus on using representations to develop the concept. In mathematics, teachers can utilize complete problem solving to prepare the students.

2. The second model is "teaching all four but more emphasis on one or two"; for example, a teacher integrated sciences and mathematics through a problem-based learning where students design a vehicle.

3. The third model is "integration at least three disciplines"; for example, the engineering processes of teamwork, identify and investigate a problem, design a solution, and testing and evaluation are added into science and mathematics units, but there are limited points across the science and mathematics subjects.

4. The fourth model is "the integration of all four subjects by a teacher". Science teacher integrates technology, engineering, and mathematics into science, for example, a school promoted new STEM initiatives that focused on designing digital solutions to real-world problems.

The other researchers also believe that STEM discipline will depend on the school curriculum (Breiner et al., 2012; McDonald, 2016). 
Table 1. The key definitions of STEM education

\begin{tabular}{|c|c|c|c|c|}
\hline \multirow{2}{*}{ Authors } & \multicolumn{4}{|c|}{ Key Definitions } \\
\hline & STEM as Discipline & STEM as Instruction & STEM as Field & STEM as Career \\
\hline Bybee (2010) & $\sqrt{ }$ & & & $\sqrt{ }$ \\
\hline $\begin{array}{l}\text { Breiner, Harkness, Johnson, \& } \\
\text { Koehler (2012) }\end{array}$ & $\sqrt{ }$ & $\sqrt{ }$ & $\sqrt{ }$ & \\
\hline Ostler (2012) & $\sqrt{ }$ & $\sqrt{ }$ & & \\
\hline $\begin{array}{l}\text { Micah Stohlmann, Moore, \& } \\
\text { Roehrig (2012) }\end{array}$ & $\sqrt{ }$ & $\sqrt{ }$ & & \\
\hline Ejiwale (2013) & $\sqrt{ }$ & & $\sqrt{ }$ & \\
\hline $\begin{array}{l}\text { Marrero, Gunning, \& Ger- } \\
\text { main-Williams (2014) }\end{array}$ & $\sqrt{ }$ & & $\sqrt{ }$ & $\sqrt{ }$ \\
\hline White (2014) & $\sqrt{ }$ & & $\sqrt{ }$ & $\sqrt{ }$ \\
\hline Fitzallen (2015) & $\sqrt{ }$ & & & \\
\hline Kelley \& Knowles (2016) & $\sqrt{ }$ & $\sqrt{ }$ & & \\
\hline McDonald (2016) & $\sqrt{ }$ & $\sqrt{ }$ & & \\
\hline Yildirim (2016) & $\sqrt{ }$ & & & \\
\hline Kubat \& Guray (2018) & $\sqrt{ }$ & $\sqrt{ }$ & & \\
\hline Thibaut et al. (2018) & $\sqrt{ }$ & $\sqrt{ }$ & & \\
\hline Wright \& Ellis (2018) & & & & $\sqrt{ }$ \\
\hline Beswick \& Fraser (2019) & $\sqrt{ }$ & $\sqrt{ }$ & & \\
\hline Pleasants et al. (2019) & $\sqrt{ }$ & & & \\
\hline $\begin{array}{l}\text { Schreffler, III, Chini, \& James } \\
\text { (2019) }\end{array}$ & & & $\sqrt{ }$ & \\
\hline
\end{tabular}

\section{STEM as Instruction}

The second key is STEM instruction. Eight of 17 studies defined STEM as instruction. In this domain, STEM education was considered as an approach that was built upon natural connection among STEM disciplines for (1) furthering students understanding of each discipline by building on students' prior knowledge; (2) broadening students' understanding of STEM disciplines through exposure to socially relevant STEM context and (3) making STEM disciplines and career more accessible and intriguing for students (Wang et al., 2011).

STEM instruction is transformed from conventional teaching, teacher-centered learning to active, student-centered learning. McDonald (2016) summarized the pedagogical instructions, including inquiry; argumentation and reasoning; digital learning; computer programming and robotics; integration of some STEM content; cooperative learning; student-centered; hands-

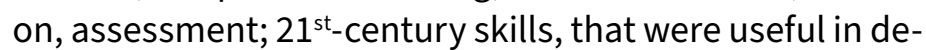
veloping student engagement and achievement in STEM disciplines. STEM instruction also referred to solving problems that described concepts and processes from science and mathematics while incorporating the teamwork and design methodology of engineering and using appropriate technology (Smith \& Karr-Kidwell, 2000).

The previous study confirmed that STEM instruction has considerable effects on the students' attitudes towards students' career interest in their future. STEM instruction also could increase the effectiveness of STEM education, make meaningful learning possible, develop relevant careers content standards and skills useful in everyday life (John et al., 2018; Maarouf, 2019; Pawilen \& Yuzon, 2019; Sari, Alici, \& Sen, 2018). Pawilen and Yuzon (2019) established six critical things that need to be 
considered in designing STEM instruction:

1. The interest of the students on the topics and activities

2. Availability of materials to be used

3. Appropriateness of the topics and activities to the learners

4. Relevance to learners' daily lives

5. Connection of the contents and activities to the K-12 curriculum

6. Integration of science, technology, engineering, and mathematics

In addition, three of the studies defined STEM instruction as a STEM curriculum in a bigger scale of education (Kubat \& Guray, 2018; Ostler, 2012; Thibaut et al., 2018). STEM instruction reveals the learning process on the class scale. Meanwhile, the STEM curriculum discusses the learning process on the school scale. In both scale, STEM was believed to provide opportunities for more relevant, less fragmented, and more stimulating experiences for learners' (Furner \& Kumar, 2007).

Any coordination of the teaching across disciplines makes some knowledge demand about the other disciplines in order to have practical conservations for coordinated planning. A capacity to collaborate, and to think creatively and innovatively about one's teaching is a minimal requirement (Beswick \& Fraser, 2019; Eckman, Williams, \& Silver-Thorn, 2016). It can be solved through STEM teachers' training in a different way than scientists, mathematicians, and engineers who contributes to all facets of responsible $21^{\text {st }}$-century learners and citizen (Ostler, 2012). The implementation of STEM instruction in an educational system that has a very established segregated and discipline-based structure that required the profound restructuring of the curriculum and lessons (Nadelson \& Seifert, 2017). Likewise, STEM instruction required numerous materials and resources for students (Pawilen \& Yuzon, 2019; Stohlmann et al., 2012). They discovered the critical content standards to learn in a STEM curriculum identified by the student teachers:

1. Science concepts: life sciences, physical sciences, chemical sciences;

2. Technology concepts: technology as tools, technology as ideas, technology as a product of science;

3. Engineering design concepts: models, designs, problem-solving, communicating ideas, planning, implementing;

4. Mathematical concepts: numbers, problem-solving, geometry, measurement, representation of math ideas using objects, symbols, and words.

\section{STEM as Field}

NSF defined STEM field broadly, including not only the standard strategies of Natural Sciences, mathematics, engineering, and computer and information, but also such behavioral sciences as psychology, economics, sociology, and political science (Green, 2006). The STEM field is described as the push for graduating more students in the science, technology, engineering, and mathematics fields. Thus, the country could maintain their competitiveness and no fall behind other countries and improve critical reasoning and logical thinking of their citizens (Breiner et al., 2012; Sadler \& Zeidler, 2004).

Five of 17 studies defined STEM as a field. Lack of research collaboration across STEM fields was considered one of the identified barriers to STEM education. Research collaboration through cluster concepts across STEM fields for an integrated curriculum will enhance connectivity and information sharing among the stakeholders (Ejiwale, 2013; Haruna \& Ibrahim, 2015).

Gandhi-Lee et al. (2017) categorized three broad factors that influenced the retention of undergraduates in STEM fields:

1. Interactions with faculty: The faculty-student interactions can have a significant impact on students' persistence in a STEM-related filed;

2. Student/faculty interactions in the classroom: Personal classroom interactions with faculty in the college setting can have a critical role in students' choice of whether to continue in STEM;

3. The environment of undergraduate science courses: Although most faculty interactions happen within a classroom, student interactions with faculty outside of formal teaching are also found to impact student retention in the STEM field positively. Positive interactions out of the classroom, those happen during office hours, during a research forum, and in a laboratory, could encourage students' continued commitment in STEM.

\section{STEM as Career}

In total, four of 17 studies revealed STEM as a career. This domain focuses on the students' career in the future, which is related to STEM fields, for example, if a student is majoring molecular biology, they will enter the STEM career as a scientist. They may or may not be exposed to technology, or mathematics or engineering, that specifically pertains to their field, but chances are they would be exposed in some way, shape, or form. Therefore, the integration in terms of STEM may or may not be occurred. However, it must be noted that they were within a STEM field (White, 2014). Some researchers revealed that 


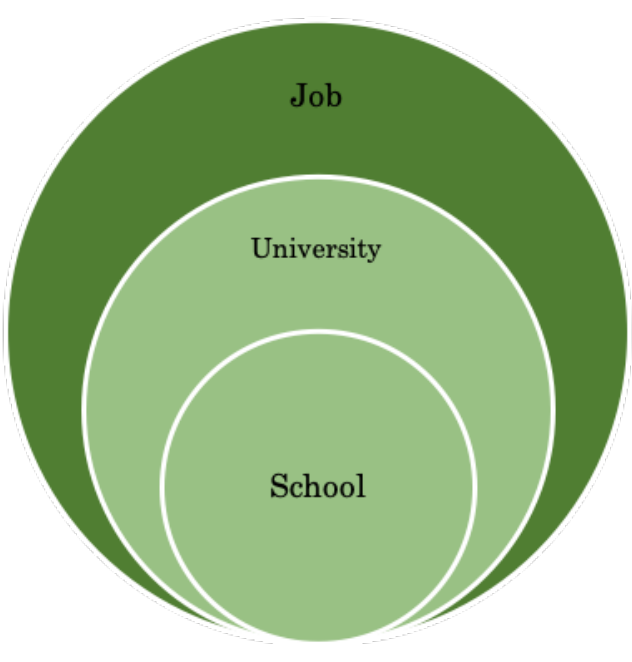

Figure 1. The Scopes in STEM Education

increasing the number of individuals qualified for and pursuing STEM careers can help the country stay competitive with others and improved the global economy through increased innovation and technology (Freeman, 2005; Lacey \& Wright, 2009). Therefore, it is vital to develop a population of college graduates with STEM degrees to meet these increasing demands (Rozek et al., 2017).

\section{The Relationship among Key Definitions}

The first two-key definitions of STEM education are covered in the school scope (Primary to secondary level), the third key definition is included in university scope (High school level), and the last key definition is revealed as job (Profession) scope that is shown in Figure 1.

STEM discipline and instruction exists idnn school level K-12 education, which are mostly implemented among the selected studies. This scope is considered as the basic implementation of STEM education, which also becomes the most critical part. Researchers believed that STEM education should start from earlier education, such as an elementary school that also provides a robust environment and supports STEM implementation (Ching et al., 2019; English, 2017; Estapa \& Tank, 2017).

Meanwhile, STEM as the field is included in the university scope because students could freely choose the STEM or non-STEM field at this level. The STEM field is called as STEM major that is not covered science, technology, engineering, and mathematics major only, but also the other majors such as information technology, natural science, statistics, chemical engineering, etc.

Based on the 17 selected studies, only five studies were conducted to identify the STEM field, which means it is rarely getting concern from the researchers. The last scope is STEM Job, with four studies worked on it. STEM education is defined as a career that also becomes the main future goal of STEM education. Students in each country are believed they could move from national competitiveness to international competitiveness through STEM career and direct/indirectly improve the global economy.

\section{CONCLUSION}

Based on the literature review, researcher reveals that the definition of STEM education is too broad and depends on the stakeholders during the STEM implementation. In this study, the researcher concludes STEM educations into four key definitions: STEM as discipline, STEM as instruction, STEM as the field, and STEM as a career. From these four key definitions, it seems that STEM discipline becomes the most frequent research as well as the fundamental definitions of STEM education. Further, these four key definitions are also covered into three scopes. STEM discipline and instruction are included in the school scope, which mostly talks about how to provide an active learning process through STEM learning. The next is a STEM field that exists in the university scope. The students are supported to choose the STEM field at the university level after learning STEM discipline in the School. Lastly, STEM career is included in a STEM job or profession as the highest scope as well as become the last goals in STEM education. The researcher is hoping this study will provide information to the other researchers as well as the stakeholders around the world on how they should focus on the implementation of STEM education.

\section{REFERENCES}

Beswick, K., \& Fraser, S. (2019). Developing mathematics teachers' 21st Century Competence for teaching in STEM contexts. ZDM, 51(6), 955-965. http://doi.org/10.1007/s11858-019-01084-2

Boe, M. V., Henriksen, E. K., Lyons, T., \& Schreiner, C. (2011). Participation in science and technology: Young people's achievement-related choices in late-modern societies. Studies in Science Education, 47(1), 37-72. https://doi.org/10.1080/03057267.2011.549621

Bozkurt, A., Ucar, H., Durak, G., \& Idin, S. (2019). The current state of the art in STEM research: A systematic review study. Cypriot Journal of Educational Sciences, 14(3), 374-383. http://doi.org/10.18844/cjes. v14i3.3447w

Breiner, J. M., Harkness, S. S., Johnson, C. C., \& Koehler, C. M. (2012). What is STEM? A discussion about conceptions of stem in education and partnerships. School Science and Mathematics, 112(1), $1-11$.

Burghardt, M. D., \& Hacker, M. (2004). Informed design: A contemporary approach to design pedagogy as the core process in technology. The Technology Teacher, 64(1), 6-8.

Bybee, R. W. (2010). What is STEM Education? American Association for the Advancement of Science, 329(5995), 996. https://doi. org/10.1126/science.1194998

Ching, Y.-H., Yang, D., Wang, S., Baek, Y., Swanson, S., \& Chittoori, B. (2019). Elementary school student development of STEM attitudes and perceived learning in a STEM integrated robotics curric- 
ulum. TechTrends, 63(5), 590-601. http://doi.org/10.1007/s11528019-00388-0

Dugger, W. E. (2010). Evaluation of STEM in the United States. Paper presented at The 6th Biennial International Conference in Technology Education Research'nda sunulmus bildiri, Gold Coast, Queensland, Australia.

Eckman, E. W., Williams, M. A., \& Silver-Thorn, M. B. (2016). An integrated model for STEM teacher cooperative educational experience. Journal of STEM Teacher Education, 51(1), 71-82. https://doi. org/10.30707/JSTE51.1

Ejiwale, J. A. (2013). Barriers to successful implementation of STEM Education. Journal of Education and Learning, 7(2), 63-74.

English, L. D. (2017). Advancing elementary and middle school STEM education. International Journal of Science and Mathematics Education, 15, 5-24. https://doi.org/10.1007/s10763-017-9802-x

Estapa, A. T., \& Tank, K. M. (2017). Supporting integrated stem in the elementary classroom: A professional development approach centered on an engineering design challenge. International Journal of STEM Education, 4(6), 1-16. https://doi.org/10.1186/s40594017-0058-3

Fitzallen, N. (2015). STEM education: What does mathematics have to offer? Paper presented at The 38th Annual Conference of the Mathematics Education Research Group of Australasia, Sunshine Coast.

Freeman, R. B. (2005). Does globalization of the scientific/engineering workforce threaten U.S economic leadership? Innovation Policy Economy, 6(6), 123-158.

Furner, J. M., \& Kumar, D. D. (2007). The mathematics and science integration argument: A stand for teacher education. Eurasia Journal of Mathematics, Science, \& Technology Education, 3(3), 185-189.

Gandhi-Lee, E., Skaza, H., Marti, E., Schrader, P., \& Orgill, M. (2017). Faculty perceptions of student recruitment and retention in STEM fields. European Journal of STEM Education, 2(1), 1-11. http://dx. doi.org/10.20897/esteme.201702

Green, M. M. (2006). Science and engineering degrees: 1977-2004. Retrieved from Arlington, VA:

Haruna, \& Ibrahim, U. (2015). The need for an effective collaboration across science, technology, engineering \& mathematics (STEM) fields for a meaningful technological development in Nigeria. Journal of Education and Practice, 6(25), 16-21.

Hobbs, L., Clark, J. C., \& Plant, B. (2018). Successful students - STEM program: Teacher learning through a multifaceted vision for STEM education. In R. Jorgensen \& K. Larkin (Eds.), STEM Education in Junior Secondary (pp. 133-168). Singapore: Springer Nature.

John, M.-S., Siburna, B., Wunnava, S., Anggoro, F., \& Dubosarsky, M. (2018). An iterative participatory approach to developing an early childhood problem-based STEM curriculum. European Journal of STEM Education, 3(3), 1-12. https://doi.org/10.20897/ejsteme/3867

Kelley, T. R., \& Knowles, J. G. (2016). A conceptual framework for integrated STEM education. Journal of STEM Education, 3(11), 1-11. doi:10.1186/s40594-016-0046-z

Kubat, U., \& Guray, E. (2018). To STEM or not to STEM? That is not the question. Cypriot Journal of Educational Sciences, 13(3), 388-399.

Lacey, T. A., \& Wright, B. (2009). Occupational employment projections to 2018. Mon Labor Rev, 132, 82-123.

Maarouf, S. A. (2019). Supporting academic growth of english language learners: Integrating Reading into STEM curriculum. World Journal of Education, 9(4), 83-96. https://doi.org/10.5430/wje. v9n4p83

Marrero, M. E., Gunning, A. M., \& Germain-Williams, T. (2014). What is
STEM education?. Global Education Review, 1(4), 1-6.

McDonald, C. V. (2016). STEM education: A review of the contribution of the disciplines of science, technology, engineering, and mathematics. Science Education International, 27(4), 530-569.

Morrison, J. S. (2006). TIES STEM education monograph series: Attributes of STEM education. Baltimore: MD: TIES

Nadelson, L. S., \& Seifert, A. L. (2017). Integrated STEM defined: Contexts, challenges, and the future. The Journal of Educational Research, 110(3), 221-223. https://doi.org/10.1080/00220671.2017.12 89775

NAE, N. A. o. E., \& NRC, N. R. C. (2009). Engineering in K-12 education: Understanding the status and improving the prospects. Washington, DC: The National Academies Press.

Ostler, E. (2012). 21st Century STEM education: A tactical model for long-range success. International Journal of Applied Science and Technology, 2(1), 28-33.

Pawilen, G. T., \& Yuzon, M. R. A. (2019). Planning a Science, technology, engineering, and mathematics (STEM) curriculum for young children: A collaborative project for pre-service teacher education students. International Journal of Curriculum and Instruction, 11(2), 130-146.

Pleasants, J., Clough, M. P., Olson, J. K., \& Miller, G. (2019). Fundamental issues regarding the nature of technology. Science \& Education, 28(3-5), 561-597. http://doi.org/10.1007/s11191-019-00056-y

Rozek, C. S., Svoboda, R. C., Harackiewicz, J. M., Hulleman, C. S., \& Hyde, J. S. (2017). Utility-value intervention with parents increases students' STEM preparation and career pursuit. Proceedings of the National Academy of Sciences. 114(5), 909-914. https://doi. org/10.1073/pnas.1607386114

Sadler, T. D., \& Zeidler, D. L. (2004). The significance of content knowledge for informal reasoning regarding socioscientific issues: Applying genetics knowledge to genetic engineering issues. Science Education, 89(1), 71-93. doi:10.1002/sce.20023

Sanders, M. (2009). STEM, STEM education. STEMmania. The Technology Teacher, 68(4), 20-26.

Sari, U., Alici, M., \& Sen, O. F. (2018). The effect of STEM instruction on attitude, career perception and career interest in a problem-based learning environment and student opinions. Electronic Journal of Science Education, 22(1), 1-21.

Schreffler, J., III, E. V., Chini, J., \& James, W. (2019). Universal design for learning in postsecondary stem education for students with disabilities: A systematic literature review. International Journal of STEM Education, 6(8), 1-10. http://doi.org/10.1186/s40594-019$0161-8$

Smith, J., \& Karr-Kidwell, P. J. (2000). The interdisciplinary curriculum: A literature review and a manual for administrators and teachers. (ERIC No. ED443172).

Stohlmann, M., Moore, T. J., McClelland, J., \& Roehrig, G. H. (2011). Yearlong impressions of a middle school STEM integration program. Middle School Journal, 43, 32-40.

Stohlmann, M., Moore, T. J., \& Roehrig, G. H. (2012). Considerations for teaching integrated STEM education. Journal of Pre-College Engineering Education Research, 2(1), 28-34. http://doi. org $/ 10.5703 / 1288284314653$

Thibaut, L., Ceuppens, S., Loof, H. D., Meester, J. D., Goovaerts, L., Struyf, A., . . Depaepe, F. (2018). Integrated STEM education: A systematic review of instructional practices in secondary education. European Journal of STEM Education, 3(1), 1-12. http://doi. org/10.20897/ejsteme/85525

Wang, H.-H., Moore, T. J., Roehrig, G. H., \& Park, M. S. (2011). STEM 
integration: Teacher perceptions and practice. Journal of Pre-College Engineering Education Research, 1(2), 1-13. https://doi. org/10.5703/1288284314636

White, D. W. (2014). What is STEM education? and why is it important? Florida Association of Teacher Educators Journal, 1(14), 1-9. Retrieved from http://www.fatel.org/journals/2014/white.pdf

Wright, R., \& Ellis, M. (2018). Where science, technology, engineering, and mathematics (STEM) graduates move: Human Capital, employment patterns, and interstate migration in the United States. Population Space and Place, 25(4), 1-13. https://doi.org/10.1002/ psp.2224

Yildirim, B. (2016). An analyses and mate-synthesis of research on STEM education. Journal of Education and Practice, 7(34), 23-33. 